\title{
ANALISIS KEAMANAN LERENG BENDUNGAN UTAMA PADA BENDUNGAN BENEL DI KABUPATEN JEMBRANA
}

\author{
I G. N. Putu Dharmayasa ${ }^{1}$, I W. Redana ${ }^{2}$, Tjok Gde Suwarsa Putra ${ }^{2}$
}

\begin{abstract}
Abstrak: Pembangunan bendungan sangat bermanfaat bagi masyarakat di sekitarnya. Oleh karena itu, perlu ditinjau kondisi keamanan bendungan ketika bendungan sedang dibangun dan kondisi ketika bendungan beroperasi pada saat ini. Kondisi keamanan berkenaan dengan perubahan ketinggian air pada hulu bendungan yang mempengaruhi besar rembesan dan keamanan lereng bendungan ketika bendungan telah beroperasi. Tinjauan keamanan bendungan ini dilakukan terhadap Bendungan Benel yang terletak di Kecamatan Melaya, Kabupaten Jembrana, Propinsi Bali.

Berdasarkan analisis yang telah dilakukan, hasil perhitungan rembesan $(q)$ pada tubuh bendungan dengan SEEP/W dan flownet menunjukkan bahwa, debit rembesan $(q)$ yang melewati tubuh bendungan dan di bawah tubuh bendungan jumlahnya kurang dari $1 \%\left(4,9206 \mathrm{~m}^{3} /\right.$ detik $)$ terhadap debit banjir rata-rata, sehingga telah memenuhi persyaratan keamanan yang ditentukan

Perhitungan angka keamanan bendungan tanpa beban gempa dan dengan beban gempa, untuk kondisi saat pembangunan, ketika bendungan beroperasi dengan muka air banjir , ketika bendungan beroperasi pada musim hujan (muka air normal), ketika bendungan beroperasi pada musim kemarau, dan ketika air bendungan surut cepat (rapid draw down) untuk lereng bagian hulu dan bagian hilir dengan SLOPE/W dan dengan metode Bishop memperoleh hasil lebih besar dari yang ditentukan dalam RSNI M-03-2002.
\end{abstract}

Kata kunci: Bendungan Benel, debit rembesan, angka keamanan

\section{MAIN DAM SLOPE SAFETY ANALYSIS OF BENEL DAM IN THE JEMBRANA REGENCY}

\begin{abstract}
Development of dam very important for community surrounding the dam. To maintain that the benefits can be continued, it is necessary to review whether the safety of dams already meet the expected requirements. Dam safety to be reviewed when the dam was built and when the dam operating at this time. Security conditions associated with changes in water level on the upstream dam that affects the seepage on the body of dam and seepage under the dam. The water level also affects the slope of the dam when the dam has been operating. Evaluation of the safety of the dam was conducted on Benel dam which located in Melaya District, Jembrana Regency, Bali Province.

The results of the calculation of seepage $(q)$ in the dam body with SEEP/W and flownet shows that, seepage discharge $(q)$ which passes through under the dam and the body of dam is less than $1 \%\left(4.9206 \mathrm{~m}^{3} / \mathrm{second}\right)$ against the average flood discharge, so it has met the security requirements.

Dam safety factor calculations without seismic load and with seismic load, for upstream slope and downstream slope when the dam was constructed, when operating with flood water level, when operating in the rainy season (normal water level), when operating in the dry season (minimum water level) and with rapid draw down condition, with SLOPE/W and the Bishop method, the safety factor obtained more than minimum requirement by RSNI M-03-2002.
\end{abstract}

Keywords: Benel dam, seepage discharge, safety factor

\footnotetext{
${ }^{1}$ Alumnus Program Studi Magister Teknik Sipil, Program Pascasarjana Universitas Udayana

${ }^{2}$ Staf Pengajar Program Studi Magister Teknik Sipil, Program Pascasarjana Universitas Udayana
} 


\section{PENDAHULUAN}

Pembangunan bendungan di suatu daerah berperan penting bagi kemajuan daerah disekitar bendungan, karena banyak manfaat yang dapat dinikmati oleh masyarakat di sekitarnya. Manfaat yang dapat diperoleh oleh masyarakat yaitu diantaranya untuk persediaan air, sebagai pembangkit listrik dan sebagai tempat rekreasi.

Agar manfaat yang diperoleh dapat berkelanjutan maka perlu diketahui keamanan bendungan apakah sudah sesuai dengan yang diharapkan ketika bendungan telah beroperasi. Oleh karena itu, perlu ditinjau kondisi keamanan bendungan ketika bendungan sedang dibangun dan kondisi ketika bendungan beroperasi pada saat ini. Kondisi keamanan berkenaan dengan perubahan ketinggian air pada hulu bendungan yang mempengaruhi besar rembesan pada tubuh bendungan dan di bawah bendungan. Ketinggian air ini juga mempengaruhi keamanan lereng bendungan ketika telah beroperasi.

Tinjauan keamanan bendungan ini dilakukan terhadap Bendungan Benel yang terletak di Kecamatan Melaya, Kabupaten Jembrana, Propinsi Bali yaitu diantaranya analisis rembesan pada tubuh bendungan dan di bawah tubuh bendungan. Analisis rembesan dilakukan terhadap kondisi muka air di hulu bendungan adalah ketika muka air di hulu bendungan adalah muka air banjir, muka air normal (musim hujan), dan muka air minimum (musim kemarau).

Untuk perhitungan keamanan bendungan adalah ketika masa pembangunan (tanpa air di hulu bendungan), ketika bendungan beroperasi dengan muka air banjir, ketika muka air normal (musim hujan), ketika muka air minimum (musim kemarau), serta ketika bendungan mengalami kondisi surut cepat (rapid draw down) maksimum.

\section{KAJIAN PUSTAKA \\ Bendungan Urugan}

Bendungan urugan adalah bangunan yang dibuat dari bahan timbunan seperti tanah, pasir dan batuan yang dibuat sedemikian rupa sehingga membentuk suatu dinding yang mampu menampung air. Bendungan urugan biasanya dibuat di lokasi yang mudah memperoleh bahan timbunan seperti tanah lempung, pasir dan batuan.

\section{Angka Keamanan dan Longsoran Pada Lereng Bendungan}

Longsor pada lereng bendungan sangat berbahaya bagi keamanan bendungan. Pada bendungan urugan, keruntuhan lereng biasanya berbentuk lingkaran. Untuk menganalisis faktor keamanan tanah yang keruntuhannya berbentuk lingkaran di gunakan metode kesetimbangan gaya atau metode kesetimbangan momen.

Keadaan kritis yang ditinjau dalam analisis keamanan lereng tubuh bendung adalah :

1. masa konstruksi (ketika sedang dibangun)

2. pada masa beroperasi : muka air banjir, musim hujan (muka air normal) dan musim kemarau (muka air minimum)

3. ketika bendungan kehilangan air secara cepat / kondisi surut cepat.

\section{Metode Bishop}

Metode Bishop adalah pengembangan metode ordinary dari Fellenius. Metode Bishop mengasumsikan bahwa tegangan geser antar segmen adalah nol. Dalam beberapa studi stabilitas lereng menunjukkan bahwa, resultante gaya sisi samping segmen dapat diabaikan tanpa suatu kesalahan yang berarti pada stabilitas. Hal ini akan mengurangi kerumitan analisis sehingga membuat analisis menjadi sederhana, analisis ini kemudian dinamakan "Simplified Bishop Method" (Gambar 1).

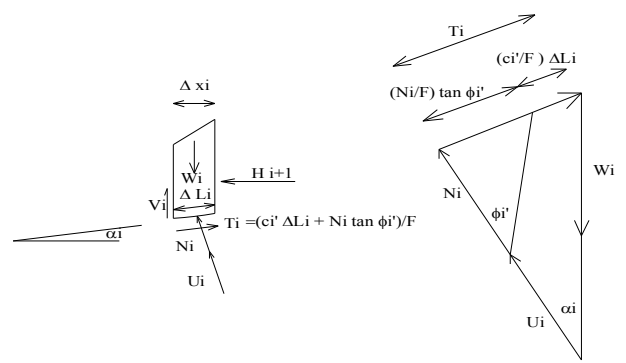

Gambar 1. Metode simplified Bishop

Gaya vertikal yang bekerja pada irisan bidang gelincir adalah:

$W_{i}=T_{i} \sin \alpha_{i}+N_{i} \cos \alpha_{i}+u_{i} \Delta x_{i}$

Gaya penggelincir sama dengan $\mathrm{T}_{\mathrm{i}}$ yaitu:

$T i=\frac{c i^{\prime} \Delta L i}{S F}+\frac{N i \tan \varphi i^{\prime}}{S F} \ldots \ldots \ldots$.

Dengan mensubstitusikan persamaan (1) ke persamaan (2), dengan nilai $\Delta x_{i}$ adalah $\Delta L_{i}$ $\cos \alpha$ maka: 


$$
\begin{aligned}
& W_{i} \\
& \left(\frac{c_{i}{ }^{\prime} \Delta L_{i}}{S F}+\frac{N_{i} \tan \varphi_{i}{ }^{\prime}}{S F}\right) \sin \alpha_{i}+N_{i} \cos \alpha_{i}+u_{i} \Delta x_{i} \ldots \ldots \\
& \ldots \ldots \ldots \ldots \ldots \ldots \ldots \ldots \ldots \ldots \ldots \ldots \ldots \ldots \ldots \ldots \ldots \ldots \\
& N_{i} \quad=\frac{W_{i}-\frac{c_{i}{ }^{\prime} \Delta x \tan \alpha_{i}}{S F}-u_{i} \Delta x_{i}}{\cos \alpha_{i}\left(\frac{\tan \varphi_{i}{ }^{\prime} \tan \alpha_{i}}{S F}+1\right)} \ldots \ldots \ldots \ldots \ldots(4) \\
& \cos \alpha_{i}\left(\frac{\tan \varphi_{i}{ }^{\prime} \tan \alpha_{i}}{S F}+1\right)=M \alpha . \ldots \ldots \ldots \ldots \ldots(5)
\end{aligned}
$$

Persamaan dari nilai keamanan adalah:

$$
S F=\frac{\sum\left(c_{i}{ }^{\prime} \Delta L_{i}+N_{i} \tan \varphi i^{\prime}\right)}{\sum W_{i} \sin \alpha_{i}} .
$$

Dengan memasukkan nilai $\mathrm{N}$ dari persamaan (4) ke persamaan (8) maka dihasilkan persamaan:

$$
S F=\frac{\sum\left(c_{i}{ }^{\prime} \Delta x_{i}+\left(W_{i}-u_{i} \Delta x\right) \tan \varphi i_{1}\right) / M \alpha_{i}}{\sum W_{i} \sin \alpha_{i}}
$$

\section{Perhitungan Keamanan Bendungan Terhadap Gempa dengan Metode Pseudostatik}

Pada metode ini perhitungan terhadap gempa dilakukan dengan memasukkan koefisien gaya gempa ke dalam perhitungan metode Bishop. Berdasarkan koefisien gaya gempa tersebut dihasilkan komponen gaya gempa horizontal $\left(F_{h}\right)$ dan gaya gempa vetikal $\left(F_{v}\right)$ sehingga menghasilkan persamaan (2.10):

$$
S F=\frac{\left.\sum\left[\left(c_{i}^{\prime} \times \Delta x_{i}+\left(\left(W_{i}-F\right)\right) \cos \alpha_{i}-u_{i} \times \Delta x_{i}-F h \sin \alpha\right) \operatorname{tanp}_{i}^{\prime}\right) \frac{1}{M_{\alpha}}\right]}{\sum\left(W_{i}-F{ }^{\prime}\right) \sin _{i}+F h \cos \alpha}
$$

Untuk mendapatkan nilai angka keamanan terhadap gempa dengan metode pseudo statik dilakukan dengan proses mencoba berulang-ulang (trial and error).

Perhitungan Keamanan Bendungan Terhadap Gempa dengan Analisis Lereng Dinamik Sederhana (Matyas, 1985)

Perhitungan keamanan lereng dinamik dilakukan dengan penurunan rumus pada tes triaksial dinamik sehingga diperoleh hubungan tekanan normal pada keruntuhan $\left(\sigma_{f c}\right)$, tekanan keliling efektif $\left(\sigma_{3 c}\right)$, tekanan geser pada keruntuhan dinamik $\left(\tau_{f f}\right)$ dan sudut keruntuhan dinamik $\left(\varphi_{f}\right)$ sebagai berikut:

$$
\begin{gathered}
\sigma_{f c}=\frac{\sigma_{1 c}+\sigma_{3 c}}{2}+\left[\frac{\sigma_{1 c}-\sigma_{3 c}}{2}\right] \cos 2 \varphi_{f} \ldots \ldots(9) \\
\sigma_{3 c}=\frac{2 \sigma_{f c}}{\left(K_{c}+1\right)\left(K_{c}-1\right) \cos 2 \varphi_{f}} \ldots \ldots \ldots \ldots \ldots(10) \\
\tau_{f f}=\frac{2 \sigma_{f c}}{\left(K_{c}+1\right)\left(K_{c}-1\right) \cos 2 \varphi_{f}}\left[\frac{K_{c}+S R-1}{2}\right] \sin 2 \varphi_{f} \ldots
\end{gathered}
$$

$\varphi_{f}=45^{\circ}+\frac{\varphi^{\prime}}{2}$

$S R=\frac{\sigma_{d c}}{2 \sigma_{3 c}}=\frac{\tau_{c}}{\sigma_{3 c}}$

$K_{c}=\frac{\sigma_{1 c}}{\sigma_{3 c}}=\frac{1+\sin \varphi_{m}^{\prime}}{1-\sin \varphi_{m}^{\prime}}$

$\varphi_{m}^{\prime}=\arctan \left(\frac{\tan \varphi^{\prime}}{F}\right)$

Perhitungan Koefisien Gempa di Indonesia

Nilai koefisien gempa dihitung berdasarkan kepada peta zona gempa Indonesia yang dipakai sebagai acuan dalam merencanakan dan merancang bangunan. Zona gempa di Indonesia di bagi menjadi 6 yaitu zone A, B, C, D, E dan F.

Untuk aplikasi dalam desain bangunan tahan gempa perlu dikoreksi pengaruh jenis tanah setempat dengan persamaan:

$$
a d=z \times a c \times v .
$$

Berdasarkan persamaan diatas maka dapat dihitung koefisien gempa dengan persamaan:

$$
k_{h}=a d / g \text {. }
$$

\section{Rembesan Pada Tubuh Bendungan}

Menurut Casagrande, garis rembesan pada tubuh bendungan mempunyai bentuk dasar parabola. Titik $\mathrm{F}$ adalah titik fokus yang merupakan titik potong antara garis dasar bendungan dengan garis keluarnya air di hilir bendungan (Gambar 2). 


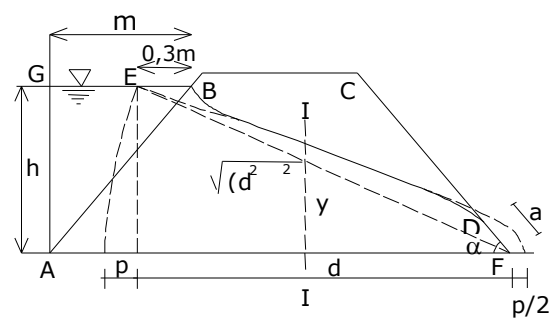

Gambar 2. Garis aliran di dalam tubuh bendungan

Sumber: EM 1110-2-1901: 6-2

Persamaan parabola:

$$
\begin{aligned}
& y^{2}=2 p x+p^{2} \\
& B E=0,3 B G \ldots \\
& d=F A-0,7 B G
\end{aligned}
$$

Untuk menentukan debit aliran dalam tubuh bendungan dibedakan dalam dua keadaan yaitu:

a. Untuk sudut lereng hilir $\alpha \geq 30^{\circ}$ dianggap garis rembesan masih sama dengan parabola dasar, debit:

$$
q=k p \text {. }
$$

b. Untuk sudut lereng hilir $\alpha<30^{\circ}$ penyimpangan garis rembesan terhadap parabola dasar cukup banyak, debit:

$$
q=k a \sin \alpha \operatorname{tg} \alpha
$$

\section{Flownet Pada Bendungan Urugan}

Cara lain untuk menghitung debit rembesan pada tubuh bendungan adalah dengan menggambar flownet. Flownet adalah cara menghitung besar debit rembesan pada tubuh bendungan dengan cara grafis. Flownet dalam tubuh bendungan ditampilkan pada Gambar 3.

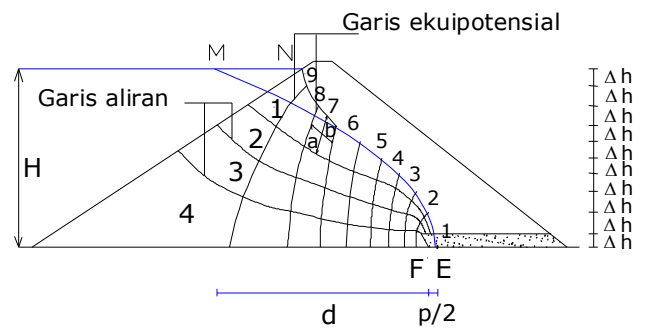

Gambar 3. Flownet pada tubuh bendungan

Maka besarnya debit adalah :

$$
q=k H\left(\frac{N_{f}}{N_{d}}\right)
$$

Agar bendungan aman maka besar debit rembesan $(q)$ yang diijinkan kurang dari $1 \%$ debit limpasan tahunan rata-rata.

\section{Rembesan Pada Bendungan Tipe Urugan Zonal}

Pada desain bendungan agar dapat mengontrol rembesan maka permeabilitas material luar lebih besar daripada material inti atau material luar dan zonal transisi dianggap sangat permeabel terhadap inti $(\mathrm{k}$ material luar / $\mathrm{k}$ inti $\geq 20$ ).

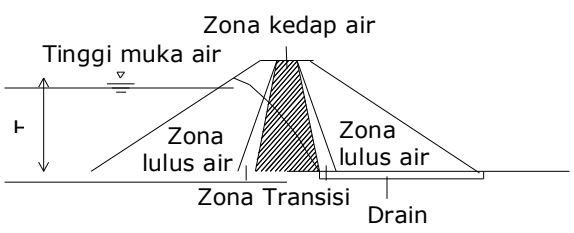

(a). Material luar apabila tidak diabaikan

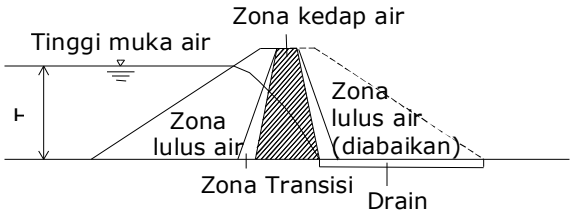

(b). Material luar di hilir apabila diabaikan

Gambar 4. Perhitungan posisi garis aliran pada bendungan zonal

Karena rembesan melalui media yang koefisien rembesannya berbeda maka akan terjadi pembelokan arah aliran pada batas kedua media yang berbeda tersebut (Gambar 11).

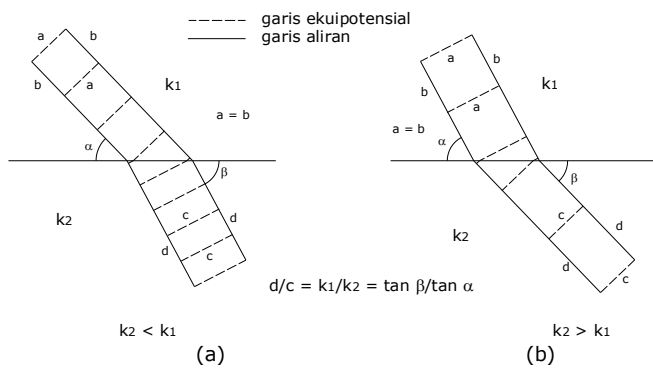

Gambar 5. Pembelokan arah aliran ketika terjadi perbedaan permeabilitas pada suatu lapisan tanah

Sumber: EM 1110-2-1901: 4-17

Kondisi untuk gambar (a) adalah $\mathrm{k}_{2}<$ $\mathrm{k}_{1}$ dan kondisi untuk gambar (b) adalah $\mathrm{k}_{2}>$ $\mathrm{k}_{1}$. Kondisi (a) dan kondisi (b) dapat dirumuskan :

$$
\frac{d}{c}=\frac{k_{1}}{k_{2}}=\frac{\tan \beta}{\tan \alpha}
$$


Rembesan di Bawah Tubuh Bendungan Urugan dengan Tanah Dasar Isotropis dan Homogen

Untuk menghitung besar rembesan yang terjadi di bawah tubuh bendungan dilakukan dengan menggunakan flownet dan cara menggambar sama dengan menggambar flownet untuk aliran pada tubuh bendungan. Besar debit untuk rembesan di bawah bendungan adalah sama dengan yang dinyatakan pada persamaan (24).

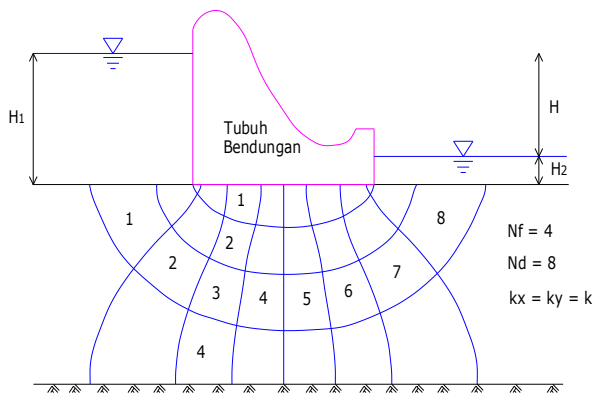

Gambar 6.

Flownet di bawah tubuh bendungan

\section{METODE PENELITIAN}

\section{Rencana Analisis}

Pelaksanaan analisis ini dimulai dengan identifikasi masalah yang selajutnya diikuti dengan pengumpulan data-data penunjang analisis. Data-data yang dikumpulkan berupa data desain bendungan, hasil pengujian bahan timbunan bendungan, ketingian air pada hulu bendungan dan uji rembesan.

\section{Metode Pengumpulan Data}

Data yang digunakan untuk penelitian ini merupakan data sekunder yang diperoleh dari proyek pembangunan Bendungan Benel. Data-data yang diperlukan berupa:

1. data-data geometri bendungan,

2. data-data tanah material timbunan bendungan,

3. koefisien permeabilitas $(k)$ material timbunan bendungan dan tanah dasar bendungan.

4. data ketinggian air pada hulu bendungan

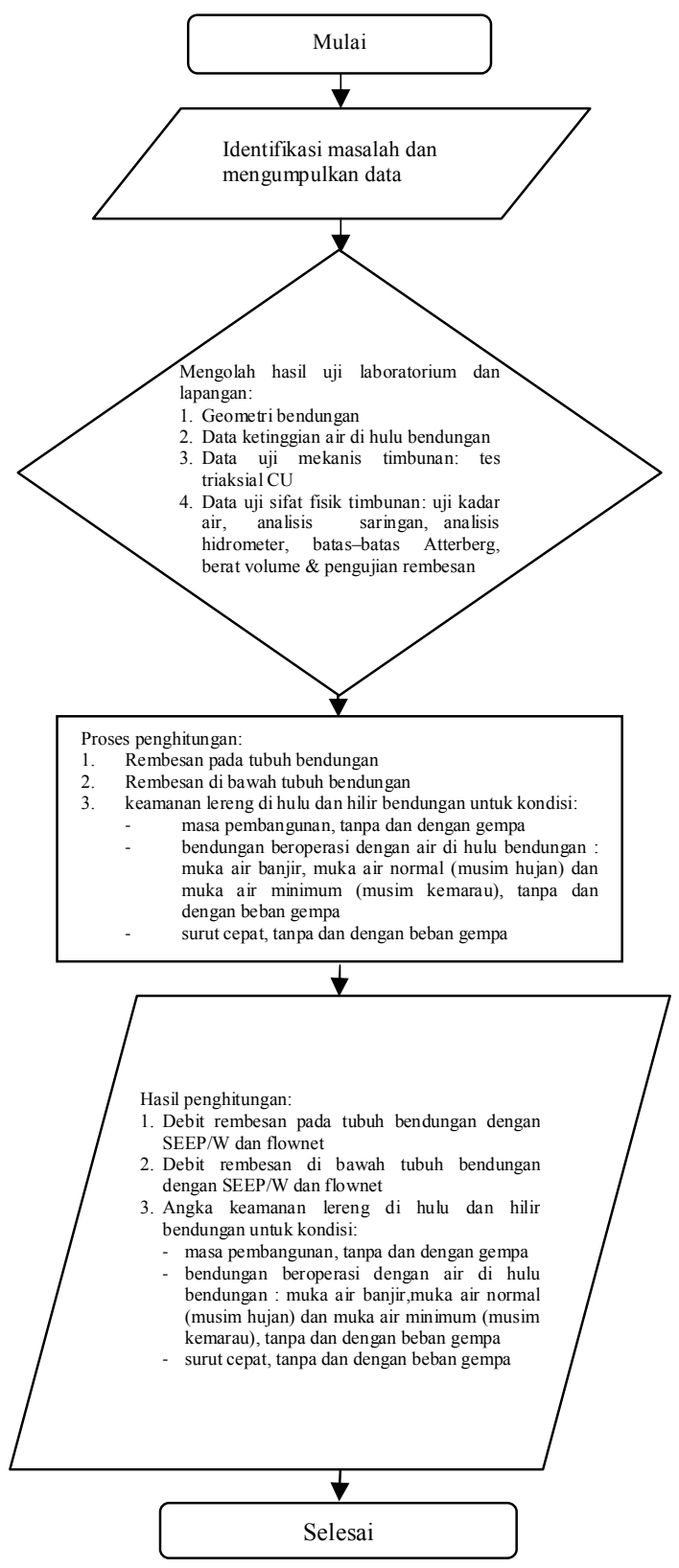

Gambar 7. Diagram alir (flowchart) analisis keamanan bendungan Benel 


\section{Perhitungan Rembesan pada Tubuh Bendungan dan di Bawah Tubuh Bendungan}

Tujuannya adalah untuk mengetahui debit rembesan yang terjadi pada tubuh bendungan dan di bawah tubuh bendungan. Perhitungan debit rembesan pada tubuh bendungan dan di bawah tubuh bendungan digunakan metode flownet. Besar debit dihitung sesuai dengan persamaan 2.4.

Perhitungan Keamanan Lereng Bendungan dengan Metode Bishop untuk Kondisi Masa Pembangunan

Pada kondisi masa pembangunan bendungan tipe urugan pengaruh tekanan air pori $\mathrm{u}_{\mathrm{i}}=0$ pada dinding tubuh bendung, sehingga bentuk persamaannya menjadi:

$S F=\frac{\sum\left[\left(c_{i}{ }^{\prime} \Delta x_{i}+W_{i} \cos \alpha_{i} \tan \varphi_{i}{ }^{\prime}\right) \frac{1}{M \alpha \alpha}\right]}{\sum W_{i} \sin \alpha_{i}}$.

Untuk kondisi dengan beban gempa persamaan menjadi:

$S F$

$$
=\frac{\sum\left[\left(c_{i}{ }^{\prime} \Delta x_{i}+\left(\left(W_{i}-F v\right) \cos \alpha_{i}-F h \sin \alpha\right) \tan \phi_{i}{ }^{\prime}\right) \frac{1}{M_{\alpha}}\right]}{\sum\left(W_{i}-F v\right) \sin \alpha_{i}+F h \cos \alpha}
$$

Perhitungan Keamanan Lereng Bendungan dengan Metode Bishop untuk Kondisi Ketika Bendungan Beroperasi

Pada kondisi bendungan beroperasi secara penuh maka perlu diperhitungkan tekanan air pada dinding tubuh bendungan bagian hulu oleh air yang mengisi bendungan serta dengan adanya tekanan air pori, sehingga persamaan menjadi:

$$
S F=\frac{\sum\left[\left(c_{i}{ }^{\prime} \Delta x_{i}+\left(W_{i} \cos \alpha_{i}-u_{i} \Delta x_{i}+h \Delta x_{i} \gamma_{w}\right) \tan \varphi_{i}{ }^{\prime}\right) \frac{1}{M \alpha_{i}}\right]}{\sum W_{i} \sin \alpha_{i}}
$$

$S F=$

Untuk kondisi dengan beban gempa persamaan menjadi:

$$
\frac{\sum\left[\left(c_{i}^{\prime} \times \Delta x_{i}+\left(\left(W_{i}-F v\right) \cos \alpha_{i}+\left(h \times \Delta x_{i} \times v_{w}\right) \cos \alpha_{i}-u_{i} \times \Delta x_{i}-F h \sin \alpha\right) \tan \varphi_{i}^{\prime}\right) \frac{I}{M_{\alpha}}\right]}{\sum\left(W_{i}-F v\right) \sin \alpha_{i}+F h \cos \alpha}
$$

Perhitungan Keamanan Lereng Bendungan dengan Metode Bishop untuk Kondisi Ketika Air Bendungan Surut Cepat (Rapid Draw Down)

Pada kondisi bendungan kehilangan air secara cepat, kondisi yang terjadi adalah adanya tekanan air pori pada tubuh bendung tetapi terjadi kehilangan tekanan air pada dinding tubuh bendung bagian hulu sehingga faktor keamanan menjadi:

$S F=$

$$
\frac{\sum\left[\left(c_{i}{ }^{\prime} \Delta x_{i}+\left(W_{i} \cos \alpha_{i}-u_{i} \Delta x_{i}\right) \tan \varphi_{i}{ }^{\prime}\right) \frac{1}{M \alpha_{i}}\right]}{\sum W_{i} \sin \alpha_{i}} \ldots
$$

Untuk kondisi dengan beban gempa persamaan menjadi:

$S F=$

$$
\frac{\sum\left[\left(c_{i}{ }^{\prime} \times \Delta x_{i}+\left(\left(W_{i}-F v\right) \cos \alpha_{i}-u_{i} \Delta x_{i}-F h \sin \alpha\right) \tan \phi_{i}{ }^{\prime}\right) \frac{1}{M_{\alpha}}\right]}{\sum\left(W_{i}-F v\right) \sin \alpha_{i}+F h \cos \alpha}
$$

\section{HASIL DAN PEMBAHASAN}

Rangkuman Data-data Untuk Perhitungan Rembesan dan Keamanan Bendungan

Berdasarkan data-data yang telah dikumpulkan, maka dapat dirangkum datadata yang diperlukan untuk melakukan perhitungan rembesan pada tubuh bendungan dan di bawah tubuh bendungan serta untuk perhitungan angka keamanan tubuh bendungan. Rangkuman data-data yang

\begin{tabular}{|c|c|c|c|c|c|c|}
\hline \multirow[b]{2}{*}{ Zona } & \multicolumn{2}{|c|}{ Berat Volume } & \multirow{2}{*}{$\begin{array}{c}\varphi^{\prime} \\
(\square)\end{array}$} & \multirow{2}{*}{$\begin{array}{c}c^{\prime} \\
\left(\mathrm{t} / \mathrm{m}^{2}\right)\end{array}$} & \multirow{2}{*}{\multicolumn{2}{|c|}{$\begin{array}{l}\text { Koefisien Rembesan }(K) \\
(\mathrm{m} / \mathrm{dt})\end{array}$}} \\
\hline & $\gamma t$ & $\gamma d$ & & & & \\
\hline Zona I (Inti Bendungan) & 1,780 & 1,314 & 21,5 & 3,4 & $1,240 \mathrm{E}-07$ & $6,515 \mathrm{E}-10$ \\
\hline Zona II (Filter Halus) & 2,165 & 1,948 & 40 (asumsi) & 0 (asumsi) & $8,080 \mathrm{E}-05$ & $1,938 \mathrm{E}-06$ \\
\hline Zona III (Filter Kasar) & 2,330 & 2,210 & 40 (asumsi) & 0 (asumsi) & $4,367 \mathrm{E}-04$ & $5,987 \mathrm{E}-05$ \\
\hline Zona IV (Rocks) & 2,222 & 2,116 & 40 (asumsi) & 0 (asumsi) & $4,367 \mathrm{E}-04$ & $5,987 \mathrm{E}-05$ \\
\hline Tanah dasar bendungan & - & - & - & - & $5,000 \mathrm{E}-07$ & $1,000 \mathrm{E}-08$ \\
\hline
\end{tabular}
diperlukan untuk perhitungan debit rembesan dan keamanan bendungan dapat dilihat pada Tabel 1 .

Tabel 1. Rangkuman data-data untuk menghitung rembesan dan keamanan lereng dari bendungan Benel 
Hasil Perhitungan Rembesan Perhitungan Rembesan di Dalam dan di Bawah Tubuh Bendungan Setelah dilakukan perhitungan maka, diperoleh hasil untuk rembesan di dalam tubuh bendungan dan di bawah tubuh bendungan seperti pada Tabel 2 .
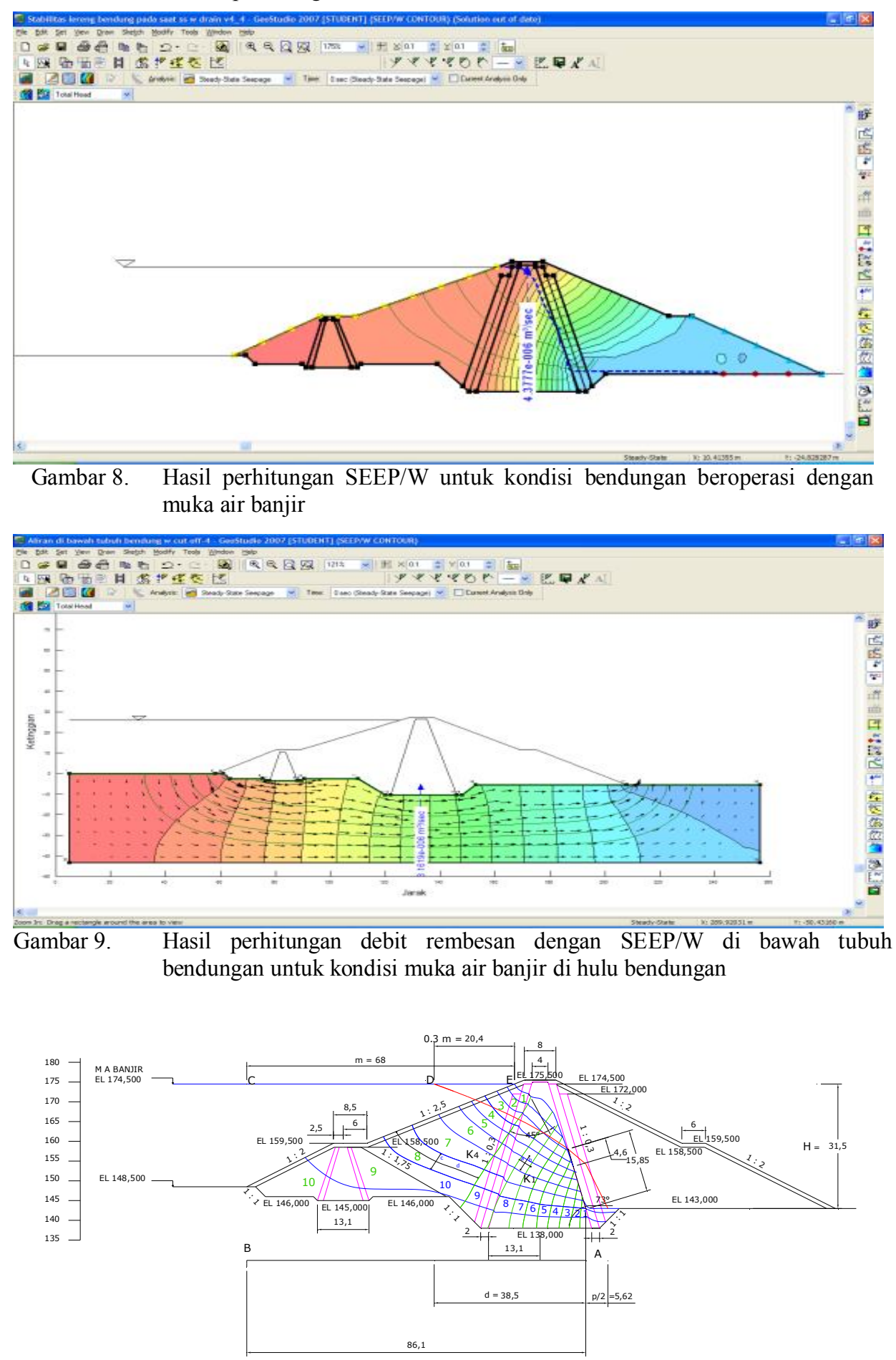

Gambar 10. Flownet pada tubuh bendungan untuk muka air banjir di hulu bendungan 


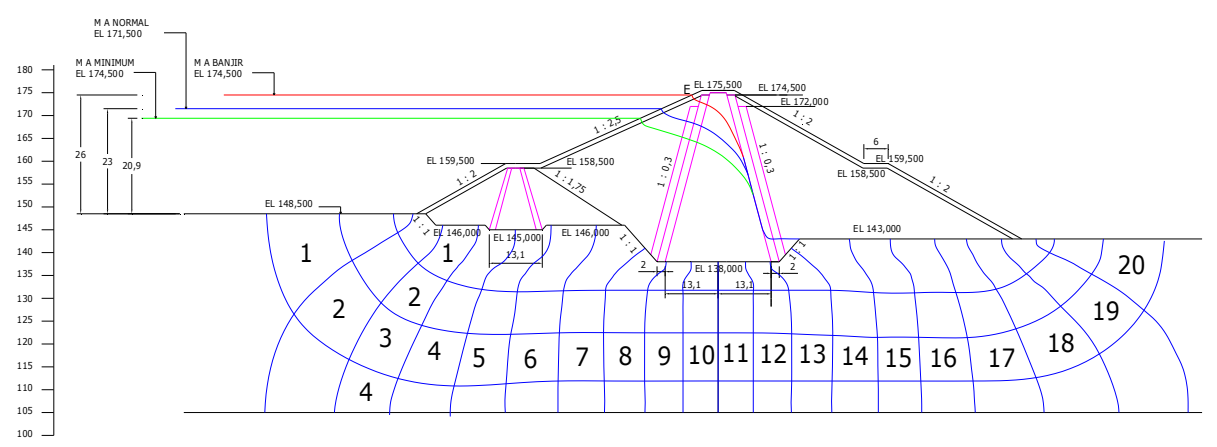

Gambar 11. Flownet di bawah tubuh bendungan

Tabel 2. Rangkuman hasil perhitungan rembesan pada tubuh bendungan dan di bawah tubuh bendungan Benel

\begin{tabular}{|c|c|c|c|c|c|c|}
\hline \multirow{3}{*}{ Metode } & \multicolumn{6}{|c|}{$\begin{array}{c}\text { Debit Rembesan }(q) \\
\left(\mathrm{m}^{3} / \text { detik) }\right.\end{array}$} \\
\cline { 2 - 7 } & \multicolumn{3}{|c|}{ Di Tubuh Bendungan } & \multicolumn{2}{c|}{ Di Bawah Tubuh Bendungan } \\
\cline { 2 - 7 } & $\begin{array}{c}\text { Muka } \\
\text { air banjir }\end{array}$ & $\begin{array}{c}\text { Muka air } \\
\text { normal } \\
\text { (musim } \\
\text { hujan) }\end{array}$ & $\begin{array}{c}\text { Muka air } \\
\text { minimum } \\
\text { (musim } \\
\text { kemarau) }\end{array}$ & $\begin{array}{c}\text { Muka } \\
\text { air banjir }\end{array}$ & $\begin{array}{c}\text { Muka air } \\
\text { normal } \\
\text { (musim } \\
\text { hujan) }\end{array}$ & $\begin{array}{c}\text { Muka air } \\
\text { minimum } \\
\text { (musim } \\
\text { kemarau) }\end{array}$ \\
\hline SEEP/W & $6.5447 \mathrm{E}-04$ & 5.1881E-04 & 4.3484E-04 & 4.7270E-04 & 4.3144E-04 & $3.9493 \mathrm{E}-04$ \\
\hline Flownet & 5.8395E-04 & 3.6983E-04 & 2.9302E-04 & 4.7093E-04 & 4.2608E-04 & $3.9468 \mathrm{E}-04$ \\
\hline
\end{tabular}

\section{Hasil Perhitungan Keamanan Lereng}

\section{Bendungan}

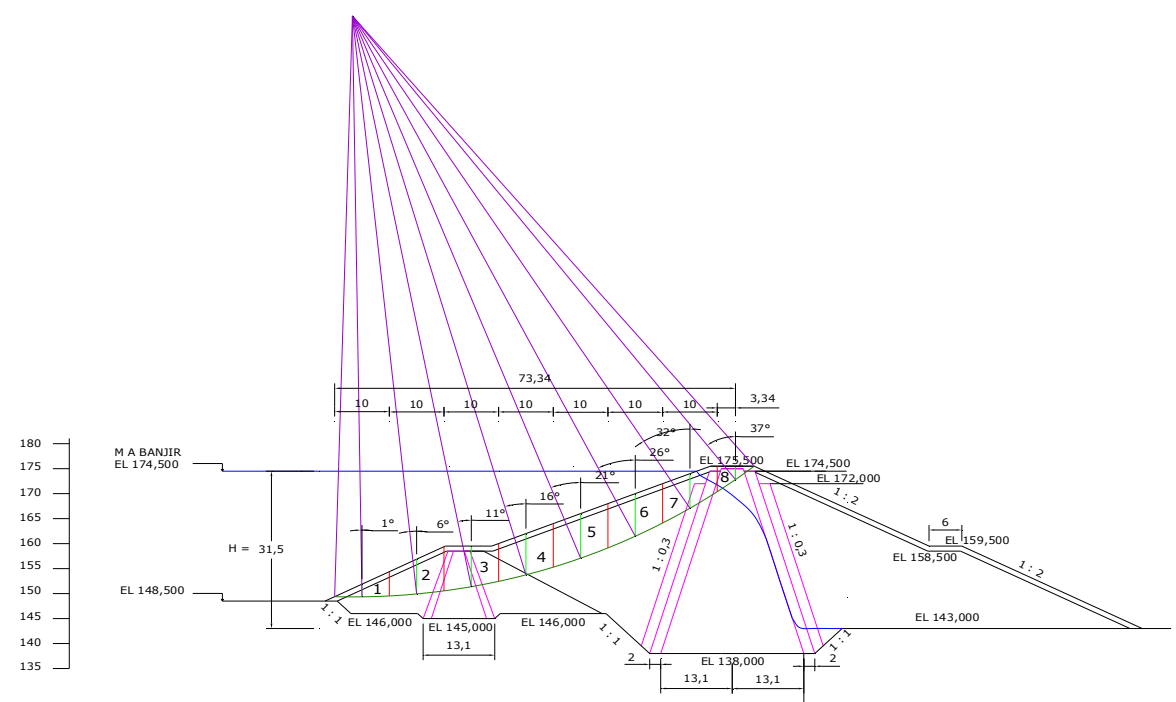

Gambar 12. Bidang gelincir pada lereng bendungan bagian hulu (upstream), untuk kondisi bendungan beroperasi dengan muka air banjir 
Tabel 3. Rangkuman hasil perhitungan keamanan pada lereng bendungan Benel dengan SLOPE/W dan metode Bishop tanpa beban gempa

\begin{tabular}{|c|c|c|c|c|c|c|c|c|c|c|}
\hline \multirow[b]{4}{*}{ Metode } & \multicolumn{10}{|c|}{ Angka Keamanan (SF) Tanpa Gempa } \\
\hline & \multicolumn{5}{|c|}{ Lereng bendungan bagian hulu bendungan (upstream) } & \multicolumn{5}{|c|}{ Lereng bendungan bagian hilir bendungan (downstream) } \\
\hline & \multirow[b]{2}{*}{ 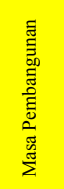 } & \multicolumn{3}{|c|}{ Bendungan Beroperasi } & \multirow[b]{2}{*}{ 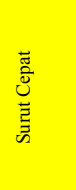 } & \multirow[b]{2}{*}{ 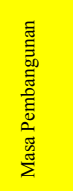 } & \multicolumn{3}{|c|}{ Bendungan Beroperasi } & \multirow[b]{2}{*}{$\begin{array}{l}\frac{\tilde{0}}{0} \\
\stackrel{0}{0} \\
\bar{\Xi} \\
\bar{\Xi}\end{array}$} \\
\hline & & 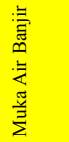 & 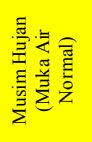 & 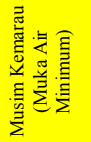 & & & 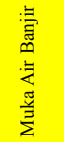 & 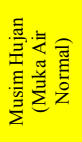 & 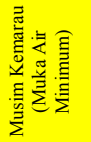 & \\
\hline SLOPE/W & 2.555 & 2.646 & 2.403 & 2.330 & 1.417 & 2.013 & 2.013 & 2.013 & 2.013 & 2.013 \\
\hline Bishop & 2.502 & 3.360 & 2.990 & 2.774 & 1.210 & 2.550 & 2.550 & 2.550 & 2.550 & 2.550 \\
\hline
\end{tabular}

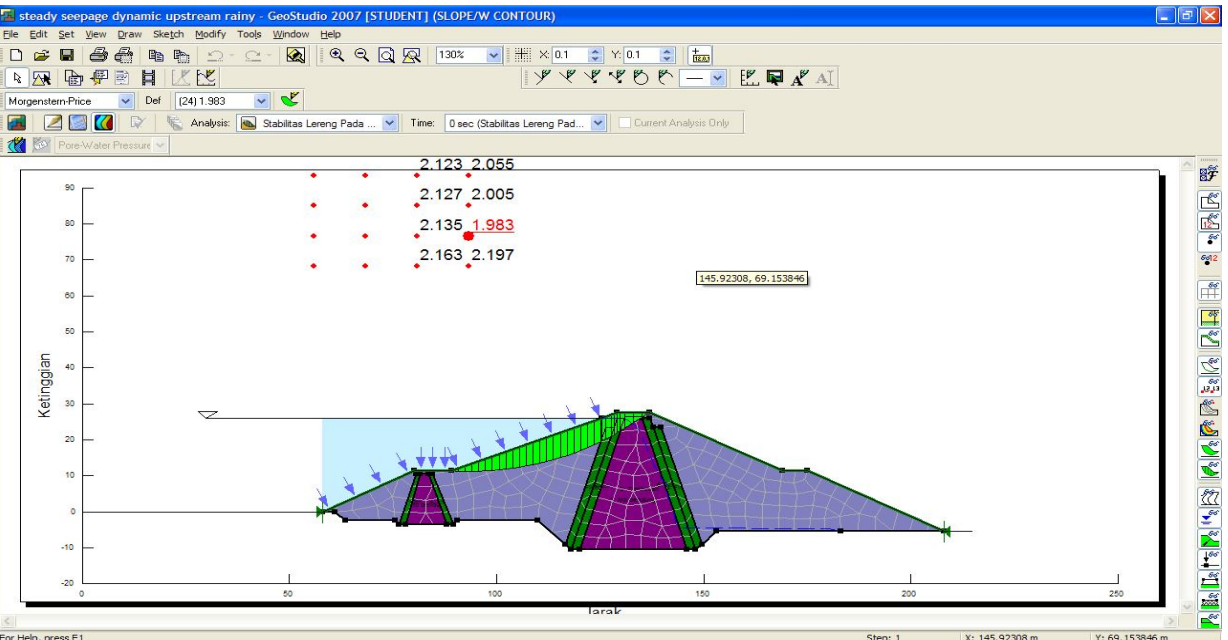

Gambar 13. Hasil perhitungan keamanan lereng bendungan bagian hulu (upstream) dengan SLOPE/W, untuk kondisi masa bendungan beroperasi dengan muka air banjir dan dengan beban gempa

Tabel 4. Rangkuman hasil perhitungan keamanan pada lereng bendungan Benel terhadap beban gempa, dihitung dengan metode pseudostatik (metode Bishop)

\begin{tabular}{|c|c|c|c|c|c|c|c|c|c|c|}
\hline \multirow[b]{4}{*}{ Metode } & \multicolumn{10}{|c|}{ Angka Keamanan (SF) Dengan Gempa Metode Pseudo Statik } \\
\hline & \multicolumn{5}{|c|}{ Lereng bendungan bagian hulu bendungan (upstream) } & \multicolumn{5}{|c|}{ Lereng bendungan bagian hilir bendungan (downstream) } \\
\hline & \multirow[b]{2}{*}{ 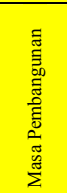 } & \multicolumn{3}{|c|}{ Bendungan Beroperasi } & \multirow[b]{2}{*}{ 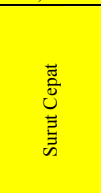 } & \multirow[b]{2}{*}{ 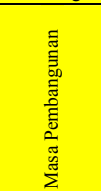 } & \multicolumn{3}{|c|}{ Bendungan Beroperasi } & \multirow[b]{2}{*}{ 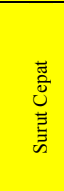 } \\
\hline & & 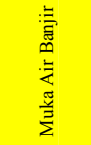 & 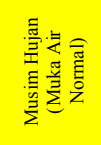 & 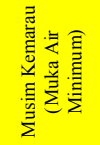 & & & 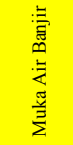 & 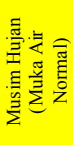 & 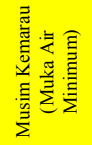 & \\
\hline SLOPE/W & - & - & - & - & - & - & - & - & - & - \\
\hline Bishop & 1.620 & 1.630 & 1.365 & 1.205 & 1.210 & 1.720 & 1.200 & 1.200 & 1.200 & 2.550 \\
\hline
\end{tabular}

Tabel 5. Rangkuman hasil perhitungan keamanan pada lereng bendungan Benel dengan SLOPE/W dan metode Bishop terhadap beban gempa, dihitung dengan analisis lereng dinamik

\begin{tabular}{|c|c|c|c|c|c|c|c|c|c|c|}
\hline \multirow[b]{4}{*}{ Metode } & \multicolumn{10}{|c|}{ Angka Keamanan (SF) Dengan Gempa Metode Dinamik } \\
\hline & \multicolumn{5}{|c|}{ Lereng bendungan bagian hulu bendungan (upstream) } & \multicolumn{5}{|c|}{ Lereng bendungan bagian hilir bendungan (downstream) } \\
\hline & \multirow[b]{2}{*}{ 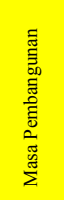 } & \multicolumn{3}{|c|}{ Bendungan Beroperasi } & \multirow[b]{2}{*}{ 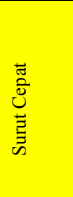 } & \multirow[b]{2}{*}{ 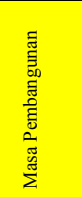 } & \multicolumn{3}{|c|}{ Bendungan Beroperasi } & \multirow[b]{2}{*}{ 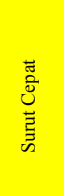 } \\
\hline & & 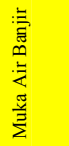 & 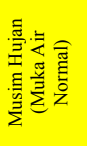 & 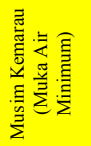 & & & 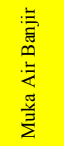 & 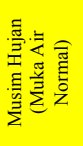 & 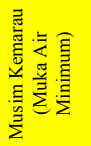 & \\
\hline SLOPE/W & 1.950 & 1.983 & 1.925 & 1.862 & 1.417 & 1.874 & 1.874 & 1.874 & 1.874 & 1.874 \\
\hline Bishop & 1.975 & 2.102 & 2.018 & 2.020 & 1.210 & 2.107 & 2.107 & 2.107 & 2.107 & 2.107 \\
\hline
\end{tabular}




\section{SIMPULAN}

Berdasarkan perhitungan yang telah dilakukan, maka dapat disimpulkan :

1. Besar rembesan yang melewati tubuh bendungan dan di bawah tubuh bendungan lebih kecil dari debit rembesan yang diijinkan yaitu 4,9206 $\mathrm{m}^{3} /$ detik.

2. Angka keamanan lereng tanpa gempa untuk kondisi pembangunan, kondisi beroperasi dengan muka air banjir, muka air nomal (musim hujan) dan muka air minimum (musim kemarau), serta kondisi surut cepat (rapid draw down) lebih besar daripada angka keamanan minimum tanpa gempa yang disyaratkan yaitu 1,3(RSNI M-03-2002)

3. Angka keamanan lereng dengan gempa untuk kondisi pembangunan, kondisi beroperasi dengan muka air banjir, muka air nomal (musim hujan) dan muka air minimum (musim kemarau), serta kondisi surut cepat (rapid draw down) lebih besar daripada angka keamanan minimum dengan gempa yang disyaratkan yaitu 1,2(RSNI M-032002)

Sehingga kondisi bendungan aman setelah beroperasi dua tahun terhadap rembesan dan longsoran pada lereng akibat perubahan ketinggian muka air waduk.

\section{SARAN}

Perlu dilakukan analisis berkala terhadap keamanan bendungan sehingga dapat dimonitor kondisi keamanan selama bendungan beroperasi di masa mendatang.

\section{DAFTAR PUSTAKA}

ASTM International, 2006, Standard Practice for Classification of Soils for Engineering Purposes (USCS), 100 Barr Harbor Drive, PO Box C700, West Conshohocken, PA 19428-2959

Astuti, Y, Aniek Masrevaniah, dan Suwanto Marsudi, 2012, Analisa Rembesan Bendungan Bajulmati terhadap Bahaya Piping untuk Perencanaan Perbaikan Pondasi, Jurnal Teknik Pengairan, Volume 3, Nomor 1, Mei 2012, 51-60

BSN, 2002, RSNI M-03-2002: Metode Analisis Stabilitas Lereng Statik Bendungan Tipe Urugan
BSN, 2002, RSNI T-01-2002: Tata Cara Desain Tubuh Bendungan Tipe Urugan

Deepankar Choudhury, Sanjay S. Nimbalkar and J.N.Mandal, 2006, Comparison of Pseudo-Static and Pseudo-Dynamic Methods for Seismic Earth Pressure on Retaining Wall, J. Ind. Geophys. Union ( October 2006 ),Vol.10, No.4, pp.263-271

Depkimpraswil, 2004, Pd T-14-2004-A: Analisis Stabilitas Bendungan Tipe Urugan Akibat Beban Gempa

Depkimpraswil, dan PT. Indira Karya, 2004, Gambar Perencanaan Waduk Benel

Dep. PU, Dirjen SDA, Satuan Kerja Balai Wilayah Sungai Bali-Penida, Pengembangan dan Konservasi SDA, 2007, Laporan Hasil Tes Tanah Borrow Area Tambahan (Alternatif) Pembangunan Waduk Benel Tahap II di Kabupaten Jembrana Bali Desember 2007

Dep. PU, Dirjen SDA, Satuan Kerja Balai Wilayah Sungai Bali-Penida, Pengembangan dan Konservasi SDA, 2008, Laporan Pelaksanaan Timbunan Pembangunan Waduk Benel di Kabupaten Jembrana

Dep. PU, Dirjen SDA, Satuan Kerja Balai Wilayah Sungai Bali-Penida, Pengembangan dan Konservasi SDA, 2008, Quality Control Laporan Bulanan (Pekerjaan Tanah) Pembangunan Waduk Benel Tahap II di Kabupaten Jembrana Bali 2008

Freeze. R.A. dan Jhon A. Cherry, 1979, Groundwater, Prentice - Hall, Englewood Cliffs, New Jersey 07632

Krahn, John, 2004, Stability Modeling with SLOPE $/ W \quad$ (An Engineering Methodology), First Edition, Revision 1, August 2004

Lambe. T. W, dan Robert V. Withman, 1979, Soil Mechanics, SI Version, Massachusetts Istitute of Technology

Redana, I Wayan,2010, Teknik Pondasi, Udayana University Press, Denpasar Bali

U.S. Departement of the Army, Corps of Engineers, 1986, Seepage Analysis and Control for Dams, Engineering Manual EM 1110-2-1901, Office of the Chief of Engineers, Washington, D.C. 